\title{
Gastroesophageal Reflux Disease: Psychological Assessment of Children and Caregivers
}

\author{
Adriane Jacinto Salustiano*, 1 \\ Orcid.org/0000-0003-1972-7560 \\ Renata Panico Gorayeb ${ }^{1}$ \\ Orcid.org/0000-0002-9127-0975 \\ Yvone Avalloni de Moraes Villela de Andrade Vicente ${ }^{1}$ \\ Orcid.org/0000-0002-2344-4953
}

${ }^{1}$ Universidade de São Paulo, Ribeirão Preto, SP, Brasil

\begin{abstract}
Gastroesophageal Reflux Disease (GERD) with high prevalence and incidence in the pediatric population is a relevant issue in public health. The literature associates family psychosocial aspects with chronic childhood illness. The present study examined the psychological alterations and peculiarities of caregivers and of children with GERD $(n=26)$ and healthy children $(n=30)$ from 3 to 12 years of age. Instruments: Sociodemographic Questionnaire and Assessment of Risk Factors for Child Illness; Hospital Anxiety and Depression Scale; and Rutter's Child Behavior Scale (A2), all of which were administered to the caregivers. Quantitative data analysis ( $\chi^{2}$ test, Fisher's exact test and ANOVA) was performed, respecting each instrument's respective criteria. In the group of children with GERD, we observed both a higher incidence of alcohol and/or drug use/abuse and higher levels of anxiety and depression on the part of the caregivers, as well as psychosocial problems involving the child. In light of the developmental level expected for this age group, greater frequency of behavioral problems was also observed. We thus conclude that there is a correlation between family psychological traits and GERD in children, stressing the need for conducting further studies and for supervising interdisciplinary clinical practices in the health care of this population.
\end{abstract}

Keywords: Pediatric gastroesophageal reflux disease, psychosocial factors, child development, chronic diseases.

\section{Doença do Refluxo Gastroesofágico: Avaliação Psicológica de Crianças e Cuidadores}

\section{Resumo}

A Doença do Refluxo Gastroesofágico (DRGE) com alta prevalência e incidência na população pediátrica é tema relevante em saúde pública. A literatura associa aspectos psicossociais familiares e

* Mailing address: Rua Albert Einstein, 1310, apto 13, Ribeirão Preto - SP, Brazil. Phone: (16) 98831-6452. E-mail: adrianejacinto.ajs@gmail.com

Financial aid: Coordenação de Aperfeiçoamento de Pessoal de Nível Superior (CAPES) Master's Program Scholarship. 
adoecimento crônico infantil. Esta pesquisa investigou alterações psicológicas e rastreou especificidades de cuidadores e crianças, de 3 a 12 anos, com DRGE $(n=26)$ e hígidas $(n=30)$. Instrumentos: Questionário Sociodemográfico e Avaliação de Fatores de Risco para Adoecimento da Criança, Escala Hospitalar de Ansiedade e Depressão, e Escala de Comportamento Infantil A2 (Rutter); todos aplicados aos cuidadores. Realizou-se análise quantitativa dos dados (Teste $\chi 2$, Teste Exato de Fisher e ANOVA), respeitando os critérios de cada instrumento. Observou-se maior incidência tanto do uso/abuso de álcool/droga, quanto do nível elevado de ansiedade e depressão do cuidador, além de problemas psicossociais, envolvendo a criança, no grupo de crianças com DRGE. Notou-se, também, maior frequência de problemas comportamentais, considerando o desenvolvimento esperado para a idade. Este estudo concluiu existir, na criança, associação entre aspectos psicológicos familiares e a DRGE, ressaltando a necessidade de aprofundar estudos e direcionar a prática clínica interdisciplinar na assistência à saúde desta população.

Palavras-chave: Doença do refluxo gastroesofágico pediátrico, fatores psicossociais, desenvolvimento infantil; doenças crônicas.

\section{Enfermedad del Reflujo Gastroesofágico: Evaluación Psicológica de Niños y Cuidadores}

\section{Resumen}

La enfermedad del reflujo gastroesofágico (ERGE) con alta prevalencia e incidencia en la población pediátrica es tema relevante en salud pública. La literatura asocia aspectos psicosociales familiares y enfermedad crónica infantil. Este estudio investigó alteraciones psicológicas y rastreó especificidades de cuidadores y niños, de 3 a 12 años, con $\operatorname{ERGE~}(n=26)$ e hígidas $(n=30)$. Instrumentos: Cuestionario Sociodemográfico y Evaluación de Factores de Riesgo para la Enfermedad del Niño, Escala Hospitalaria de Ansiedad y Depresión, y Escala de Comportamiento Infantil A2 (Rutter); todos aplicados a los cuidadores. Se realizó un análisis cuantitativo de los datos (Prueba $\chi 2$, Test Exacto de Fisher y ANOVA), respetando los criterios de cada instrumento. Se observó mayor incidencia tanto del uso / abuso de alcohol / droga, como del alto nivel de ansiedad y depresión del cuidador, y problemas psicosociales involucrando al niño, en el grupo de niños con ERGE. Así como, se notó mayor frecuencia de problemas conductuales, considerando el desarrollo esperado para la edad. Este estudio concluyó que existe asociación entre aspectos psicológicos familiares y la ERGE en el niño, resaltando la necesidad de profundizar estudios y dirigir la práctica clínica interdisciplinaria en la asistencia a la salud de esta población.

Palabras clave: Enfermedad del reflujo gastroesofágico pediátrico, factores psicosociales, desarrollo infantil; enfermedades crónicas.

Gastroesophageal reflux disease (GERD) is considered a common chronic pathology in Western countries, being of greater prevalence among the pediatric population ( 7 to $20 \%$ ). Consequently, it is a relevant public-health theme. It causes a negative impact on the quality of life of the ill and their caregivers, increasing public healthcare costs and the risk of comorbidities, especially respiratory pathologies (Amaral, 2012; Cachoeira, 2013; Cohen, Bueno de Mesquita, \& Mimouni, 2015; Ferreira et al.,
2014; Norton \& Penna, 2000; Pilli, Jiwane, \& Krishnan, 2017; Slater \& Rothenberg, 2017).

In recent years, there has been a gradual increase in knowledge concerning Gastroesophageal Reflux (GER), making a more accurate clinical diagnosis possible, given the wide range of symptoms observed in infants, children, adolescents and adults. Such symptoms are the most frequent reason for seeking a medical consultation, especially in the area of pediatric gastroenterology (de 
Benedictis \& Bush, 2017; Kleinman et al., 2006; Sherman et al., 2009; Singendonk, Brink, et al., 2017; Singendok, Tabbers, Benninga, \& Langendam, 2017; Tolia, Wuerth, \& Thomas, 2003; Vandenplas \& Hauser, 2015).

Pathological Gastroesophageal Reflux (GERD) is classified into two types: (a) primary, in which the symptoms of the reflux precede any complications, such as reflux esophagitis, esophageal stenosis, Barrett's esophagus, recurrent pneumonia, apnea, bronchospasms, malnutrition, excessive irritability, hematemesis, melena, eating difficulties, chronic cough, nocturnal cough, sudden death and otorhinolaryngologic complications; and (b) secondary, when it is associated with preexisting diseases and/or anatomical and structural alterations of the upper digestive tract (Gold, 2008; Hoffman, De Greef, Haesendonck, \& Tack, 2010; Mousa \& Nassan, 2017; Norton \& Penna, 2000; Vandenplas \& Hassall, 2002; Vandenplas \& Hauser, 2015; Vandenplas et al., 2009).

In addition to the organic aspects of the disease, emotional problems also cause functional alterations in the body and favor the appearance or maintenance of the disease in children. Accordingly, it is highly necessary to also consider the psychosocial aspects involved in chronic illness and in the quality of life of children and caregivers (Booster, Oland, \& Bender, 2016; Cordeiro, Gualberto, Brasil, Oliveira, \& Silva, 2014; Ferro \& Boyle, 2015; Lau et al., 2014; Pilli et al., 2017; Wood, Miller, \& Lehman, 2015).

According to the theory of human development, stressful events with a physical (trauma, pain, limitations secondary to the illness) and/or psychological cause (fear, stress, anxiety, insecurity, problems with social interrelations) should be considered factors with a significant impact on the quality of life of the family and on the healthy development of the child, capable of occasioning physical and mental alterations, especially chronic ones. Accordingly, it is considered important to assess the risk factors and protection factors involved in the characteristics of the family dynamics and of each child. Two types of risk factors associated with childhood pathologies are considered: (a) biological - chronic illnesses, genetic factors, prematurity, parasite infections and other factors; and (b) psychosocial - low socioeconomic status, inadequate schooling of caregivers, lack of physical and verbal stimulation of the child, use of punishment or physical aggression, parental psychopathology, and alcoholism or drug abuse in the family, among others. Such factors should be assessed in comparison with the protection factors: access to health services, adequate health care, and the familial and social support network (Crepaldi, Rabuske, \& Gabarra, 2006; Koolhaas et al., 2011).

Analysis of parental psychosocial functioning can aid clinical interventions, given that the psychological and social problems of parents (e.g. anxiety and depression) influence the psychosocial functioning and well being of their children, as well as influencing adherence to the child's treatment. One study indicated reduced control of asthma when caregivers of asthmatic children exhibited disorders related to anxiety or depression. The same occurs in children with sickle cell anemia: the parents' stress is directly associated with both the severity of the illness and the increase in the demand for health services. Accordingly, assessing parental psychosocial functioning makes it possible for doctors to identify issues that influence the treatment of children with chronic illnesses (Garralda, 1994; van Oers et al., 2014).

In this sense, familiarity with the relationship between caregivers and children is an important diagnostic instrument for the pediatrician. In light of the day-to-day challenges involved in caring for chronically ill children, it is worth stressing the need for investments in health professionals' attention to and supervision of caregivers, aiming at promoting the well being and quality of life of such children, since illness affects the life of the child and the family in the same way that family dynamics and psychosocial conditions influence the illness of the child (van Oers et al., 2014).

Hence, understanding the psychological traits both of children with GERD and of their caregivers increases one's comprehension of 
the difficulties observed in this population and of the specificities associated with the child's illness. Consequently, the present study assessed psychosocial risk factors, signs of anxiety, and depression in caregivers, and the behavior patterns of children clinically diagnosed with primary GERD, and analyzed such aspects' relationship with the disease, as well as differences and/or peculiarities of the groups under study.

\section{Method}

We conducted a prospective clinical study featuring collection and analysis of quantitative data - of 56 caregivers of children (of both sexes and with ages ranging from 3 to 12 years) under medical observation at the data collection locations, distributed into two groups: (a) Experimental Group - 26 caregivers of children clinically diagnosed with primary GERD; and (b) Control Group - 30 caregivers of healthy children. The exclusion criteria common to both groups were the following: children and caregivers under psychological observation; children with a history of chronic illnesses different from those in the study; and siblings with a history of chronic illness.

The following instruments were employed: Sociodemographic Questionnaire and Risk Factor Assessment; Hospital Anxiety and Depression Scale (HADS); and Rutter's Child Behavior Scale (ECIA2; Portuguese version abbreviation). The instruments were responded to at health care centers in the city of Ribeirão Preto (São Paulo, Brazil) during a single psychological assessment session lasting from 20 to 30 minutes for each subject. The study's ethical issues were explained, and the informed consent forms were read and filled out subsequent to the participants' acceptance. Data collection occurred in a secluded setting in which the participants declared feeling at ease to answer the questionnaires.

For the quantitative analysis of the data collected for this study, a significance level of $p$ $\leq .05$ was adopted. The analysis was performed in accordance with the literature concerning instrument validation and adaptation. We opted for conducting statistical analysis of each variable in each instrument, bearing in mind the study's objective of tracking specific variables of the child and the caregiver, as well as observing the specificities of each group. Represented by numerical results, the data collected via the psychological instruments were analyzed comparatively between the groups. The tests we employed were the Chi-Square Test $\left(\chi^{2}\right)$ and Fisher's Exact Test (ANOVA); and, when the general test attained the significance level, we administered the ANOVA tests (Kruskal-Wallis Test and Mann-Whitney $U$ Test).

The present project was APPROVED by the Research Ethics Committee of the University of São Paulo School of Medicine Clinical Hospital - Ribeirão Preto (HCFMRP-USP; abbreviation in Portuguese), via decision no. 1,283,890 (October 16, 2015). For data collection, we received authorization from the individuals responsible for the collection locations, as well as approval by the Ribeirão Preto Municipal Board of Health. Informed consent forms were filled out and were signed by the caregivers. After the study's objectives were explained, the subjects were assured of their right to refuse to participate, without the possibility of such refusal altering the child's treatment at the institution.

\section{Results}

With respect to the characterization of the sample, the comparative analysis of the data related to age, sex, schooling, parentage, type of family arrangement, parental marital status, occupation, social support network, religion and housing conditions, of both the children and the caregivers, did not exhibit significant differences in the distribution between the groups.

The caregivers' perceptions as to psychosocial risk factors (situations of relational difficulty involving the child, as well as situations involving bullying, discrimination or stress for the child) revealed psychosocial problems in $42.3 \%$ of the caregivers in the group of children 
with GERD (G1) and in $13.3 \%$ of the caregivers in the group of normal children (G2; $p=.011)$. Thus, the group of children with GERD exhibited greater frequency of psychosocial risk factors when compared to the other group (Table 1).
Alcohol and/or drug use/abuse on the part of caregivers or family members closely related to the child was more frequent in the GERD group $(23.1 \%)$ than it was in the normal group $(0.0 \%$; $p=.006$; Table 1).

Table 1

Risk Factors for Illness in Children with GERD vs. Healthy Children (simple response frequency)

\begin{tabular}{ccc}
\hline & Psychosocial & Alcohol/Drug Abuse \\
\hline GERD & $42.3 \%$ & $23.1 \%$ \\
Healthy & $13.3 \%$ & $0.0 \%$ \\
& $p=.011$ & $p=.006$ \\
\hline
\end{tabular}

The present study revealed that $69.2 \%$ of the caregivers in the group of children with GERD evidenced signs of anxiety (26.9\% to a severe degree), whereas only $3.3 \%$ of the caregivers in the group of normal children exhibited anxiety $(p=.001)$. With respect to caregivers considered depressive, $34.6 \%$ were identified in the group of children with GERD; and 3.3\%, in the group of normal children $(p=.005)$. In the comparative analysis, significant differences were also perceived for both anxiety and depression. Along these lines, predominance of anxiety in caregivers from the group of children with GERD stands out when compared to the group of normal children (Table 2).

Table 2

Anxiety and Depression in Parents of Children with GERD vs. Healthy Children (simple response frequency)

\begin{tabular}{|c|c|c|c|c|}
\hline & Anxiety & Levels & Depression & Levels \\
\hline GERD & $69.2 \%$ & $\begin{array}{c}\text { 23.1\% Slight } \\
\text { 19.2\% Moderate } \\
\text { 26.9\% Severe }\end{array}$ & $34.6 \%$ & $\begin{array}{c}\text { 3.8\% Slight } \\
\text { 15.4\% Moderate } \\
\text { 15.4\% Severe }\end{array}$ \\
\hline \multirow[t]{2}{*}{ Healthy } & $3.3 \%$ & $\begin{array}{c}0.0 \% \text { Slight } \\
3.3 \% \text { Moderate } \\
0.0 \% \text { Severe }\end{array}$ & $3.3 \%$ & $\begin{array}{c}3.3 \% \text { Slight } \\
0.0 \% \text { Moderate } \\
0.0 \% \text { Severe }\end{array}$ \\
\hline & $p=.001$ & $p=.001$ & $p=.005$ & $p=.004$ \\
\hline
\end{tabular}

Regarding the child behavior scale, a difference between the groups was observed in the total score of the "health problems" subscale $(p=.001)$. The comparative analysis revealed that the frequency of responses indicating perception of the child as irritable/nervous was greater among the GERD group's caregivers than among the healthy group's caregivers ( $p=$ .001; Table 3).

With respect to the total score of the "habits" subscale, a significant difference was observed in the comparison between the groups $(p=.001)$; and the caregivers from the group of children with GERD perceived feelings of severe fear in the children to a greater extent than was perceived by the caregivers from the group of healthy children ( $p=.001$; Table 3$)$.

In relation to the "affirmations concerning child behavior" subscale, higher scores were observed, via the caregivers' perceptions, in the GERD group than in the healthy group, for the following variables: impatient/restless 
$(p=.015)$, rejected by other children in social interactions $(p=.016)$, very worried $(p=.001)$, irritable $(p=.002)$, sad/anguished $(p=.041)$, frequent nail-biting behavior ( $p=.001)$, difficulty in concentrating on and remaining engaged in activities for more than two minutes $(p=$
$.003)$, and timid/withdrawn in the presence of strangers $(p=.049)$. In the comparative analysis of the groups in terms of the total score for this subscale, a difference between the groups was observed, with a significance level of $p=.001$ (Table 3).

Table 3

Analysis of the Behavior of Children with GERD vs. Healthy Children (mean rank of the scores)

\begin{tabular}{cccc}
\hline & Health Problems & Habits & Behaviors \\
\hline GERD & 55.48 & 54.27 & 57.17 \\
Healthy & 27.45 & 28.10 & 25.67 \\
& $p=.001$ & $p=.001$ & $p=.001$ \\
\hline
\end{tabular}

In the final analysis of the Rutter Scale, children classified as "requiring psychological or psychiatric follow-up" represented $80.8 \%$ of the group of children with GERD and $20.0 \%$ of the group of normal children $(p=.001)$. The comparative analysis revealed a higher ratio of children with a neurotic $(p=.001)$ and antisocial $(p=.046)$ profile in the group of children with GERD as compared to the group of healthy children (Table 4).

Table 4

Analysis of the Needs and Behavioral Profiles of Children with GERD vs. Healthy Children (mean rank of the scores)

\begin{tabular}{cccc}
\hline & With Psychological/Psychiatric Needs & Neurotic Profile & Antisocial Profile \\
\hline \multirow{2}{*}{ GERD } & 58.75 & 55.62 & 44.50 \\
Healthy & 24.18 & 29.88 & 32.27 \\
& $p=.001$ & $p=.001$ & $p=.046$ \\
\hline
\end{tabular}

\section{Discussion}

The following factors are considered psychosocial risks to child development: socioeconomic condition; inadequate schooling of caregivers; insufficient physical and verbal stimulation of the child; situations involving physical punishment, alcoholism and/or drug abuse in the family; and situations involving conflicts in the social interactions of the child. Hence, the greater the number of child development risk factors, the greater the probability of the child becoming mentally and physically ill. Along these lines, it is worth assessing the specific conditions of each child's context and network of protection factors, thus avoiding child stress and promoting the child's resilience (Crepaldi et al., 2006).

Separately, the above risk factors do not amount to a specific cause of child illness, but they are an indicator of complex issues within the child's environment, justifying the occurrence of psychopathology. Stressful events induce a high level of anxiety and interfere with the child's behavior and expression, a fact that is associated with the development of physical, emotional and even psychiatric disorders. Factors such as a poor repertoire of 
skills in dealing with the child, substance use/ abuse, psychological problems, low self-esteem, authoritarianism, demonstrations of anger, lack of empathy, stress, marital violence, and family dysfunction can indicate a situation of psychological vulnerability (Bee, 1995; Bowden et al., 2015; Caminha, 1999; Reppold, Pacheco, Bardagi, \& Hutz, 2002; Rutter, 1985; Simões, Farate, Soares, \& Pocinho, 2009).

The psychological resources of the caregivers in their interactions with the children contribute to adapting to the disease situation. The ill child's emotional maladjustment is associated more with the way in which the family deals with the situation than with the child's behavior itself. Stress, insecurity, guilt, exacerbated feelings, anxiety, depressive symptoms and/or any psychopathology on the part of the caregiver produce a negative impact on the child's health and on coping with the disease, causing both health-related and behavioral problems (Angerami-Camon, Nicoletti, \& Chiattone, 2009; Castro \& Piccinini, 2002; Furtado \& Lima, 2003; Im, Park, Oh, \& Suk, 2014; Zhang, Wei, Shen, \& Zhang, 2015).

The antisocial profile of a child derives from externalized behaviors, such as a bad mood, nervousness, hyperactivity, impatience/restlessness, destructiveness, frequent disobedience, stubbornness, jealousy, excessive anger, and impulsiveness. In contrast, the so-called neurotic profile derives from internalized behaviors, such as asthma or respiratory crises, nocturnal/diurnal enuresis, encopresis, moodiness, nervousness, difficulties when arriving at school or refusal to enter, a scattered glance, shyness, anxiety, exaggerated worriedness, excessive attachment to adults, and sadness. Such problematic profiles are associated with maladjustments, especially in the relational dynamics of the child with his/ her caregivers. In their social interactions, children from turbulent homes tend to imitate the behavior patterns they have learned (Bandura, 1976; Graminha, 1998; Loechner, Starman, Galuschka, \& Tamm, 2018).

One study associated maternal depression with the development of antisocial behavior in children, stressing the influence of the genetic and environmental factors of maternal depression on this type of behavior (KimCohen, Moffitt, Taylor, Pawlby, \& Caspi, 2005). Maternal depression has also been associated with the development of episodic stress and Attention Deficit Hyperactivity Disorder (ADHD) in children (Feurer, Hammen, \& Gibb, 2016; Sfelinioti \& Livaditis, 2017).

Other studies have demonstrated a correlation between the dimensions of parents' mental health and a high risk of children developing psychosocial problems and mental and behavioral disorders. In light of this scenario, an adequate support network for the children is necessary. Such children also perceive the importance of social support, especially from mental health professionals, considering that they live together with parents who have mental problems (Drost \& Schippers, 2015; Drost, van der Krieke, Sytema, \& Schippers, 2016; Karimzadeh, Rostami, Teymouri, Moazzen, \& Tahmasebi, 2017; Rodrigues \& Nogueira, 2016; Schoen, 2016; Yamamoto \& Keogh, 2017).

The family's importance stands out as a foundation for developing the identity and producing the behaviors of the child. Hence, the parents' anxiety and stress are associated with the child's irritability, and vice versa. Accordingly, observing this mutual vulnerability in the mother-child relationship makes it possible for pediatric health professionals to identify the mental health problems existing in the child's environment (Drost \& Schippers, 2015; Drost et al., 2016; Karimzadeh et al., 2017; Kingsbury, Clavarino, Mamun, Saiepour, \& Najman, 2017; Pratta \& Santos, 2007; Yamamoto \& Keogh, 2017).

Lastly, the child's temperament, the health conditions, and the interaction between the child and his/her family members are considered the three main factors associated with children's behavioral problems (Silvares \& Souza, 2008).

\section{Conclusion}

The main psychosocial risk factors to healthy child development present within the familial and social context of the children with 
GERD were the following: alcohol and drug use/abuse by caregivers and/or family members closely tied to the child and psychosocial relational problems.

The mood profile observed in the caregivers of children with GERD was characterized by high levels of anxiety and depression. The problematic behavior patterns of children with GERD were classified as neurotic and antisocial.

In light of the scarce literature on the subject and the difficulty to find a more upto-date review of the theme, we recommend expanding the studies concerning the disease's impact on the daily routine of children with GERD and their caregivers and investigating the probable psychosocial risk factors involved in the development and maintenance of the disease. We suggest that health professionals employ a more comprehensive clinical approach to assisting this population, as well as taking into consideration the psychological factors related to the child falling ill.

\section{References}

Amaral, D. M. (2012). Doença do refluxo gastroesofágico em idade pediátrica (Unpublished master's thesis). Universidade do Porto, Portugal.

Angerami-Camon, V. A., Nicoletti, E. A., \& Chiattone, H. B. C. (2009). $O$ doente, $a$ psicologia e o hospital. São Paulo, SP: Cengage Learning.

Bandura, A. (1976). Social learning theory. Englewood Cliffs, NJ: Prentice-Hall.

Bee, H. L. (1995). The developing child ( $7^{\text {th }}$ ed.). New York: HarperCollins.

Booster, G. D., Oland, A. A., \& Bender, B. G. (2016). Psychosocial factors in severe pediatric asthma. Immunology and Allergy Clinics of North America, 36(3), 449-460. doi: 10.1016/j. iac.2016.03.012

Bowden, M. R., Stormon, M., Hardikar, W., Ee, L. C., Krishnan, U., Carmody, D., ...Hazell P. (2015). Family adjustment and parenting stress when an infant has serious liver disease: The Australian experience. Journal of Pediatric Gastroenterology and Nutrition, 60(6), 717-722. doi: 10.1097/MPG.0000000000000742
Cachoeira, Y. (2013). Gestão da DRGE pediátrica. Nature Reviews Gastroenterology \& Hepatology, 11(3), 147-157. doi: 10.1038/nrgastro.2013.199

Caminha, R. M. (1999). A violência e seus danos a crianças e ao adolescente. In Associação de Apoio à Criança e ao Adolescente (Ed.), Violência doméstica (pp. 43-60). Brasília, DF: Fundo Internacional de Emergência para a Infância das Nações Unidas.

Castro, E. K., \& Piccinini, C. A. (2002). Implicações da doença orgânica crônica na infância para as relações familiares: Algumas questões teóricas. Psicologia: Reflexão e Crítica, 15(3), 625-635. doi: 10.1590/S0102-79722002000300016

Cohen, S., Bueno de Mesquita, M., \& Mimouni, F. B. (2015). Adverse effects reported in the use of gastroesophageal reflux disease treatments in children: A 10 years literature review. British Journal of Clinical Pharmacology, 80(2), 200208. doi: 10.1111/bcp.12619

Cordeiro, J. A. B. L., Gualberto, S. M., Brasil, V. V., Oliveira, G. B., \& Silva, A. M. T. C. (2014). Dificuldades enfrentadas pelos pais de crianças com doença do refluxo gastroesofágico. Acta Paulista de Enfermagem, 27(3), 255-259. doi: 10.1590/1982-0194201400043

Crepaldi, M. A., Rabuske, M. M., \& Gabarra, L. M. (2006). Modalidades de atuação do psicólogo em psicologia pediátrica. In M. A. Crepaldi, M. B. M. Linhares, \& G. B. Perosa (Eds.), Temas em psicologia pediátrica (pp. 13-55). São Paulo, SP: Casa do Psicólogo.

de Benedictis, F. M., \& Bush, A. (2017). Respiratory manifestations of gastrooesophageal reflux in children. Archives of Disease in Childhood. doi: 10.1136/ archdischild-2017-312890

Drost, L. M., \& Schippers, G. M. (2015). Online support for children of parents suffering from mental illness: A case study. Clinical Child Psychology and Psychiatry, 20(1), 53-67. doi: 10.1177/1359104513496260

Drost, L. M., van der Krieke, L., Sytema, S., \& Schippers, G. M. (2016). Self-expressed strengths and resources of children of parents with a mental illness: A systematic review. International Journal of Mental Health Nursing, 25(2), 102-115. doi: 10.1111/inm.12176

Ferreira, C. T., Carvalho, E., Sdepanian, V. L., Morais, M. B., Vieira, M. C., \& Silva, L. 
R. (2014). Gastroesophageal reflux disease: Exaggerations, evidence and clinical practice. Jornal de Pediatria, 90(2), 105-118. doi: 10.1016/j.jped.2013.05.009

Ferro, M. A., \& Boyle, M. H. (2015). The impact of chronic physical illness, maternal depressive symptoms, family functioning, and self-esteem on symptoms of anxiety and depression in children. Journal of Abnormal Child Psychology, 43(1), 177-187. doi: 10.1007/s10802-014-9893-6

Feurer, C., Hammen, C. L., \& Gibb, B. E. (2016). Chronic and episodic stress in children of depressed mothers. Journal of Clinical Child \& Adolescent Psychology, 45(3), 270-278. doi: $10.1080 / 15374416.2014 .963859$

Furtado, M. C. C., \& Lima, R. A. G. (2003). O cotidiano da família com filhos portadores de fibrose cística: Subsídios para a enfermagem pediátrica. Revista Latino-Americana de Enfermagem, 11(1), 66-73. doi: 10.1590/S010411692003000100010

Garralda, M. E. (1994). Chronic physical illness and emotional disorder in childhood. British Journal of Psychiatry, 164(1), 8-10. doi: 10.1192/ bjp. 164.1 .8

Gold, B. D. (2008). Comparing GERD manifestations in children and adults. Gastroenterology \& Hepatology, 4(1), 40-44. Retrieved from https://www.ncbi.nlm.nih.gov/pmc/articles/ PMC3394470/

Graminha, S. S. V. (1998). Recursos metodológicos para pesquisas sobre riscos e problemas emocionais e comportamentais na infância. In G. Romanelli \& Z. M. Biasoli-Alves (Eds.), Diálogos metodológicos sobre prática de pesquisa (pp. 71-86). Ribeirão Preto, SP: Legis Summa.

Hoffman, I., De Greef, T., Haesendonck, N., \& Tack, J. (2010). Esophageal motility in children with suspected gastroesophageal reflux disease. Journal of Pediatric Gastroenterology and Nutrition, 50(6), 601-608. doi: 10.1097/ MPG.0b013e3181c1f596

Im, Y. J., Park, E. S., Oh, W. O., \& Suk, M. H. (2014). Parenting and relationship characteristics in mothers with their children having atopic disease. Journal of Child Health Care, 18(3), 215-229. doi: 10.1177/1367493513485824

Karimzadeh, M., Rostami, M., Teymouri, R., Moazzen, Z., \& Tahmasebi, S. (2017). The association between parental mental health and behavioral disorders in pre-school children. Electronic Physician, 9(6), 4497-4502. doi: 10.19082/4497

Kim-Cohen, J., Moffitt, T. E., Taylor, A., Pawlby, S. J., \& Caspi, A. (2005). Maternal depression and children's antisocial behavior: Nature and nurture effects. Archives of General Psychiatry, 62(2), 173-181. doi: 10.1001/archpsyc.62.2.173

Kingsbury, A. M., Clavarino, A., Mamun, A., Saiepour, N., \& Najman, J. M. (2017). Does having a difficult child lead to poor maternal mental health? Public Health, 146, 4655. doi: 10.1016/j.puhe.2017.01.001

Kleinman, L., Rothman, M., Strauss, R., Orenstein, S. R., Nelson, S., Vandenplas, Y., ...Revicki, D. A. (2006). The infant gastroesophageal reflux questionnaire revised: Development and validation as an evaluative instrument. Clinical Gastroenterology and Hepatology, 4(5), 588596. doi: 10.1016/j.cgh.2006.02.016

Koolhaas, J. M., Bartolomucci, A., Buwalda, B., de Boer, S. F., Flügge, G., Korte, S. M., ...Fuchs, E. (2011). Stress revisited: A critical evaluation of the stress concept. Neuroscience and Biobehavioral Reviews, 35(5), 1291-1301. doi: 10.1016/j.neubiorev.2011.02.003

Lau, G. Y., Patel, N., Umasunthar, T., Gore, C., Warner, J. O., Hanna, H., ...Boyle, R. J. (2014). Anxiety and stress in mothers of foodallergic children. Pediatric Allergy Immunology, 25(3), 236-242. doi: 10.1111/pai.12233

Loechner, J., Starman, K., Galuschka, K., \& Tamm, J. (2018). Preventing depression in the offspring of parents with depression: A systematic review and meta-analysis of randomized controlled trials. Clinical Psychology Review, 60(3), 1-14. doi: 10.1016/j.cpr.2017.11.009

Mousa, H., \& Hassan, M. (2017). Gastroesophageal reflux disease. Pediatric Clinics of North America, 64(3), 487-505. doi: 10.1016/j. pcl.2017.01.003

Norton, R. C., \& Penna, F. J. (2000). Refluxo gastroesofágico. Jornal de Pediatria, 76(Supl. 2), S218-224. doi: 0021-7557/00/76-Supl.2/ S218

Pilli, S., Jiwane, A., \& Krishnan, U. (2017). Quality of life in children who have undergone fundoplication surgery for the treatment of gastroesophageal reflux disease: A review of 
literature. Diseases of the Esophagus, 30(5), 1-5. doi: 10.1093/dote/dow017

Pratta, E. M. M., \& Santos, M. A. (2007). Família e adolescência: A influência do contexto familiar no desenvolvimento psicológico de seus membros. Psicologia em Estudo, 12(2), $247-$ 256. doi: 10.1590/S1413-73722007000200005

Reppold, C. T., Pacheco, J., Bardagi, M., \& Hutz, C. (2002). Prevenção de problemas de comportamento e desenvolvimento de competências psicossociais em crianças e adolescentes: Uma análise das práticas educativas e dos estilos parentais. In C. S. Hutz (Ed.), Situações de risco e vulnerabilidade na infância e na adolescência: Aspectos teóricos e estratégias de intervenção (pp. 7-51). São Paulo, SP: Casa do Psicólogo.

Rodrigues, O. M. P. R., \& Nogueira, S. C. (2016). Práticas educativas e indicadores de ansiedade, depressão e estresse maternos. Psicologia: Teoria e Pesquisa, 32(1), 35-44. doi: 10.1590/0102-37722016012293035044

Rutter, M. (1985). Resilience in the face of adversity. British Journal of Psychiatry, 147(6), 598-611. doi: 10.1192/bjp.147.6.598

Schoen, T. H. (2016). Behavioral problems in children and adolescents with nocturnal enuresis. Psicologia Argumento, 34(84), 15-28. doi: 10.7213/psicol.argum.34.084.AO02

Sfelinioti, S., \& Livaditis, M. (2017). Association of maternal depression with children's attention deficit hyperactivity disorder. Psychiatriki, 28(3), 251-258. doi: 10.22365/jpsych.2017.283.251

Sherman, P. M., Hassall, E., Fagundes-Neto, U., Gold, B. D., Kato, S., Koletzko, S., ...Vandenplas, Y. (2009). A global, evidence-based consensus on the definition of gastroesophageal reflux disease in the pediatric population. The American Journal of Gastroenterology, 104(5), 12781295. doi: 10.1038/ajg.2009.129

Silvares, E. F. M., \& Souza, C. L. (2008). Discórdia conjugal: Distúrbios psicológicos infantis e avaliação diagnóstica comportamentalcognitiva. Psicologia: Teoria e Prática, 10(1), 200-213. Retrieved from http://pepsic.bvsalud. org/pdf/ptp/v10n1/v10n1a15.pdf

Simões, S., Farate, C., Soares, I., \& Pocinho, M. (2009). Práticas educativas parentais $e$ qualidade dos comportamentos de vinculação das crianças em idade escolar. Paper presented at the II Congresso de Investigação em
Enfermagem Ibero-Americano e de Países de Língua Oficial Portuguesa (p. 89), Coimbra, Portugal: Escola Superior de Enfermagem de Coimbra.

Singendonk, M. M. J., Brink, A. J., Steutel, N. F., van Etten-Jamaludin, F. S., van Wijk, M. P., Benninga, M. A., \& Tabbers, M. M. (2017). Variations in definitions and outcome measures in gastroesophageal reflux disease: A systematic review. Pediatrics. doi: 10.1542/peds.20164166

Singendonk, M. M. J., Tabbers, M. M., Benninga, M. A., \& Langendam, M. W. (2017). Pediatric gastroesophageal reflux disease: Systematic review on prognosis and prognostic factors. Journal of Pediatric Gastroenterology and Nutrition. doi: 10.1097/ MPG.0000000000001697

Slater, B. J., \& Rothenberg, S. S. (2017). Gastroesophageal reflux. Seminars in Pediatric Surgery, 26(2), 56-60. doi: 10.1053/j. sempedsurg.2017.02.007

Tolia, V., Wuerth, A., \& Thomas, R. (2003). Gastroesophageal reflux disease. Review of presenting symptoms, evaluation, management, and outcome in infants. Digestive Diseases and Sciences, 48(9), 1723-1729. doi: 10.1023/A:1025486710231

van Oers, H. A., Haverman, L., Limperg, P. F., van Dijk-Lokkart, E. M., Maurice-Stam, H., \& Grootenhuis, M. A. (2014). Anxiety and depression in mothers and fathers of a chronically ill child. Maternal and Child Health Journal, 18(8), 1993-2002. doi: 10.1007/s10995-0141445-8

Vandenplas, Y., \& Hassall, E. (2002). Mechanisms of gastroesophageal reflux and gastroesophageal reflux disease. Journal of Pediatric Gastroenterology and Nutrition, 35(2), 119-136.

Vandenplas, Y., \& Hauser, B. (2015). An updated review on gastro-esophageal reflux in pediatrics. Expert Review of Gastroenterology \& Hepatology, 9(12), 1511-1521. doi: 10.1586/ 17474124.2015.1093932

Vandenplas, Y., Rudolph, C. D., Di Lorenzo, C., Hassall, E., Liptak, G., Mazur, ...European Society for Pediatric Gastroenterology Hepatology and Nutrition. (2009). Pediatric gastroesophageal reflux clinical practice guidelines: Joint recommendations of the North American Society 
for Pediatric Gastroenterology, Hepatology, and Nutrition (NASPGHAN) and the European Society for Pediatric Gastroenterology, Hepatology, and Nutrition (ESPGHAN). Journal of Pediatric Gastroenterology and Nutrition, 49(4), 498-547. doi: 10.1097/MPG.0b013e3181b7f563

Wood, B. L., Miller, B. D., \& Lehman, H. K. (2015). Review of family relational stress and pediatric asthma: The value of biopsychosocial systemic models. Family Process, 54(2), 376-389. doi: 10.1111/famp.12139

Yamamoto, R., \& Keogh, B. (2017). Children's experiences of living with a parent with mental illness: A systematic review of qualitative studies using thematic analysis. Journal of Psychiatric and Mental Health Nursing. doi: 10.1111/jpm.12415
Zhang, Y., Wei, M., Shen, N., \& Zhang, Y. (2015). Identifying factors related to family management during the coping process of families with childhood chronic conditions: A multi-site study. Journal of Pediatric Nursing, 30(1), 160173. doi: 10.1016/j.pedn.2014.10.002
Received: $23 / 01 / 2018$

$1^{\text {st }}$ revision: $15 / 05 / 2018$

$2^{\text {nd }}$ revision: $10 / 06 / 2018$

Accepted: 12/06/2018 